ISSN 2525-4804

\title{
PHYSIOLOGICAL PARAMETERS OF COTTON CULTIVARS IN WEST PAULISTA
}

\author{
Lucas Aparecido Manzani Lisboa ${ }^{1}$; Matheus Luis Oliveira Cunha ${ }^{1}$; Samuel Ferrari ${ }^{1}$; Fernando Takayuki \\ Nakayama $^{2}$; Paulo Alexandre Monteiro de Figueiredo ${ }^{1}$
}

\begin{abstract}
:
Cotton varieties develop differently because they present different physiological characteristics in production environments. This study aimed to know the physiological characteristics of cotton. The experiment was carried out at the São Paulo Agribusiness Technology Agency (APTA), Alta Paulista region. The experimental design used was Entirely Randomized (DIC), with six cotton cultivars: IMA5801B2RF; FM975WS; TMG47B2RF; TMG81WS; FM944GL and IACRDN. Where the following physiological parameters were determined: Assimilation rate $\mathrm{CO}_{2}$, leaf transpiration, stomatal conductance, internal concentration of $\mathrm{CO}_{2}$ in the substomatic chamber and efficient use of water. The cotton varieties showed different physiological characteristics, the IMA5801B2RF variety had the lowest performance, which may reflect low productivity. Further physiological studies are needed to understand the Cotton varieties behavior
\end{abstract}

Keywords: Gossypium hirsutum; plant physiology; transpiration; stomatal conductance.

\section{PARÂMETROS FISIOLÓGICOS DE CULTIVARES DE ALGODOEIRO NO OESTE PAULISTA}

\section{RESUMO:}

As variedades de algodão se desenvolvem de maneiras diferentes, por apresentar características fisiológicas diferentes nos ambientes de produção. Este estudo teve como objetivo conhecer as características fisiológicas do algodão. O experimento foi realizado na Agência Paulista de Tecnologia do Agronegócio (APTA), região da Alta Paulista. O delineamento experimental utilizado foi inteiramente casualizado (DIC), com seis cultivares de algodão: IMA5801B2RF; FM975WS; TMG47B2RF; TMG81WS; FM944GL e IACRDN. Onde foram determinados os seguintes parâmetros fisiológicos: Taxa de assimilação de $\mathrm{CO}_{2}$, transpiração foliar, condutância estomática, concentração interna de $\mathrm{CO}_{2}$ na câmara subestomática e uso eficiente da água. As variedades de algodão apresentaram características fisiológicas distintas, sendo que a variedade IMA5801B2RF apresentou o pior desempenho, o que pode refletir baixa produtividade. Mais estudos fisiológicos são necessários para entender o comportamento das variedades de algodão.

Palavras-chave: Gossypium hirsutum; fisiologia vegetal; transpiração; condutância estomática.

\footnotetext{
1 São Paulo State University (Unesp), College of Agricultural and Technological Sciences, Dracena, Brazil. E-mail: lucas.lisboa@unesp.br

${ }^{2}$ Paulista Agribusiness Technology Agency, Regional Paulista Regional Camp, Adamantina, Brazil. 


\section{INTRODUCTION}

Cotton (Gossypium hirsutum L. r. Latifolium Hutch) is among the most important fibrous crops in the world, with a cultivated area of approximately 35 million hectares. In Brazil, in the 2017/2018 harvest, 1.17 million hectares of cotton were grown with an average yield of $1,677 \mathrm{~kg} \mathrm{ha}^{-1}$ of plume, with Brazil being the second largest world producer of fiber (Abrapa, 2019). Feather production in the 2018/2019 harvest is expected to reach 2.4 million tonnes, with an increase of $20 \%$ over the previous harvest (Conab, 2019).

The main cotton producing states in Brazil are Mato Grosso and Bahia, representing about $80 \%$ of the cultivation area in the country, the main characteristics of these regions being medium and sandy soil. In the state of São Paulo the West is the second largest producing microregion with around 1,800 hectares of crop in the 2018/2019 harvest (Appa, 2019).

Cotton, among the plants cultivated by man, is one of the most complex, being very demanding in management practices and for having a set of particular physiological characteristics (Beltrão, 2006). The physiology is affected by environmental factors, with the water status in plants being one of the main factors that affect leaf growth, it is extremely important for agricultural production (Taiz et al., 2017).

The great diversity in upland cotton allows it to be cultivated in two regions of Brazil
(Central-West and Northeast). The magnitude of genotype $\mathrm{X}$ environment interaction across most traits complicates selecting the best variety (Teodoro et al., 2019). Therefore, this study aimed to know the physiological characteristics of cotton.

\section{MATERIAL AND METHODS}

The experiment was carried out in December 2018, at the São Paulo Agribusiness Technology Agency (APTA), Alta Paulista region, located in Adamantina city, State of São Paulo, with geographical coordinates $21^{\circ} 40^{\prime} 24.024^{\prime \prime S}$ and $51^{\circ} 8^{\prime} 31.088^{\prime \prime} \mathrm{W}$ and an approximate altitude of $420 \mathrm{~m}$. The region's climate is characterized as Aw according to Köppen and Geiger, it has rainy summers and dry winters; with an annual average temperature of $22.1{ }^{\circ} \mathrm{C}$ and $1204 \mathrm{~mm}$ of accumulated rainfall in the year.

The experimental design used was Entirely Randomized (DIC), with six cotton cultivars: IMA5801B2RF; FM975WS; TMG47B2RF; TMG81WS; FM944GL and IACRDN.

The soil was classified as Argisol redyellow dystrophic (Embrapa et al., 2013) with good drainage and its chemical attributes, after analysis (Raij et al., 1996) are shown in Table 1.

Table 1 - Chemical attributes of the soil in the experiment area when sowing cotton. Adamantina, 2018.

\begin{tabular}{|c|c|c|c|c|c|c|c|c|c|c|c|}
\hline $\mathrm{pH}$ & $\mathrm{OM}$ & $\mathrm{P}$ & $\mathrm{K}$ & $\mathrm{Ca}$ & $\mathrm{Mg}$ & $\mathrm{H}+\mathrm{Al}$ & $\mathrm{Al}$ & SB & CEC & V\% & $\mathrm{m} \%$ \\
\hline $\mathrm{CaCl}_{2}$ & $\mathrm{~g} \mathrm{dm}^{-3}$ & $\mathrm{mg} \mathrm{dm}^{-3}$ & & --- & 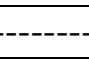 & - & $\mathrm{mm}$ & $\mathrm{dm}^{-3}$ & ----- & (-) & \\
\hline 4.6 & 12.0 & 26.0 & 2.9 & 8.0 & 4.0 & 20.0 & 1.0 & 14.9 & 34.9 & 43.0 & 6.0 \\
\hline
\end{tabular}

OM: Organic matter; SB: Sum of bases; CEC: Cation exchange capacity; V\%: Base saturation; m\%: Saturation by aluminum. 
The soil was corrected according to the requirements of the crop according to Fuzatto et al. (2014), where the $300 \mathrm{~kg} \mathrm{ha}^{-1}$ planting fertilizer was used with the NPK fertilizer 08-28-16 and was applied $1.0 \mathrm{t} \mathrm{ha}^{-1}$ of dolomitic limestone for liming the soil. Each plot had six lines five meters long, with a density of six plants per linear meter.

At 70 days after sowing, the first fully expanded leaf was selected at random from the apex of five plants within each plot, and five measurements were taken per plant, totaling 25 measurements per cotton variety, where the following parameters were determined physiological: Assimilation rate $\mathrm{CO}_{2}(\mathrm{~A}-\mu \mathrm{mol}$ $\left.\mathrm{CO}_{2} \mathrm{~m}^{-2} \mathrm{~s}^{-1}\right)$, Leaf transpiration $\left(\mathrm{E}-\mathrm{mmol} \mathrm{H}_{2} \mathrm{O} \mathrm{m}^{-2}\right.$ $\left.\mathrm{s}^{-1}\right)$, Stomatal conductance $\left(\mathrm{GS}-\mathrm{mol} \mathrm{H}_{2} \mathrm{O} \mathrm{m}^{-2} \mathrm{~s}^{-1}\right.$ ), Internal concentration of $\mathrm{CO}_{2}$ in the substomatic chamber $\left(\mathrm{Ci}-\mu \mathrm{mol} \mathrm{mol}{ }^{-1}\right.$ ) and Efficient use of water $\left(\mathrm{EUW}-\mathrm{mol} \mathrm{CO}_{2} \mathrm{~mol} \mathrm{H}_{2} \mathrm{O}^{-1}\right)$, determined through the formula:

$$
\mathrm{EUW}=\frac{\mathrm{A}}{\mathrm{E}}
$$

The initial condition for the measurement was according to the luminous intensity of the environment in the period between 10:00 am to 2:00 $\mathrm{pm}$ in full sun, where the equipment of Gas and Infrared Analyzer (IRGA), brand ADC BioScientific Ltd, model LC-Pro. Where five measurements were made in five plants, making up 25 measurements per variety.

For statistical evaluation of treatments, the variables were subjected to analysis of variance by the $\mathrm{F}$ test $(\mathrm{p}<0.05)$ and their means compared by the Skott-Knott test at 5\% probability (Banzatto and Kronka, 2013) and the program was used statistic $R$ (R Core Team, 2009).

\section{RESULTS AND DISCUSSION}

According to analysis of variance (Table 2), it was observed that there was a statistical difference for all physiological characteristics, analyzed in this research, of cotton cultivars cultivated in West Paulista.

Table 2 - Analysis of variance of the $\mathrm{CO}_{2}$ assimilation rate (A), Transpiration (E), Stomatal conductance (GS), and Internal $\mathrm{CO}_{2}$ concentration in the substomatic chamber $(\mathrm{Ci})$ and efficient use of water (EUW) of the cotton cultivars. Adamantina, 2018.

\begin{tabular}{lccccc}
\hline & $\mathbf{A}$ & $\mathbf{E}$ & $\mathbf{G S}$ & $\mathbf{C i}$ & $\mathbf{E U W}$ \\
\hline $\mathrm{p}$ value & 0.0077 & 0.0015 & 0.0001 & 0.0020 & 0.0391 \\
Meaningfulness & $* *$ & $* *$ & $* *$ & $* *$ & $*$ \\
Mean standard error & 0.57 & 0.08 & 0.04 & 4.36 & 0.15 \\
\hline
\end{tabular}

According to Pimentel (1998) the C3 plants, which is the case of cotton, show photosynthetic activity in an interval between 12 and $25 \mu \mathrm{mol} \mathrm{m} \mathrm{m}^{-2}$. By analyzing the $\mathrm{CO}_{2}$ assimilation rate results presented in Figure 1, it can be seen that the values of the cotton cultivars are within the acceptable parameters mentioned above. The cultivar TMG81WS had the lowest averages for a $\mathrm{CO}_{2}$ assimilation rate, while the other cultivars had averages between 23.12 and $21.72 \mu \mathrm{mol} \mathrm{CO} 2 \mathrm{~m}^{-2} \mathrm{~s}^{-1}$.
Regarding cotton leaf transpiration, the cultivars IMA5801B2RF, FM975WS and TMG47B2RF had the highest values, with averages between 3.61 to $3.55 \mathrm{mmol} \mathrm{H}_{2} \mathrm{O} \mathrm{m}^{-2} \mathrm{~s}^{-1}$ (Figure 2). The other cultivars had approximately $8.5 \%$ less sweat. The low results presented by cultivars TMG81WS, FM944GL, IACRDN, demonstrate a greater water retention capacity exhibited by these cultivars, probably due to the stomatal mechanism (Marur and Faria, 2006). 
Sweating is highly affected by environmental factors, especially temperature and the deficit in air saturation. Differences in this parameter, when the plants are grown under similar conditions, can demonstrate an efficient or less efficient stoma apparatus, effective in saving water for the plant (Xiong et al., 2018; Lisboa et al., 2019).

In the evaluation of stomatal conductance, the variety IMA5801B2RF presented the highest values $\left(1.22 \mathrm{~mol} \mathrm{H}_{2} \mathrm{O} \mathrm{m}{ }^{-2}\right.$ $\mathrm{s}^{-1}$ ), standing out from the other cultivars the according Figure 3. Low indices of stomatal conductance leads to a lower influx of $\mathrm{CO}_{2}$ into the chloroplasts, so there will be reductions in photosynthetic rates (Tatagiba et al., 2015). Low values of stomatal conductance (gs) indicates that photosynthesis would not be affected by stomatal closure or by the concentration of $\mathrm{CO}_{2}$ within the sub-stomatal chamber, but by biochemical factors that would be restricting $\mathrm{CO}_{2}$ reduction (Marur and Faria, 2006). Galon et al. (2010) reported that stomatal conductance and $\mathrm{CO}_{2}$ level are directly associated with stomata opening, that is, the higher the stomatal conductance the greater the number of open stomata and consequently there will be greater assimilation of $\mathrm{CO}_{2}$.

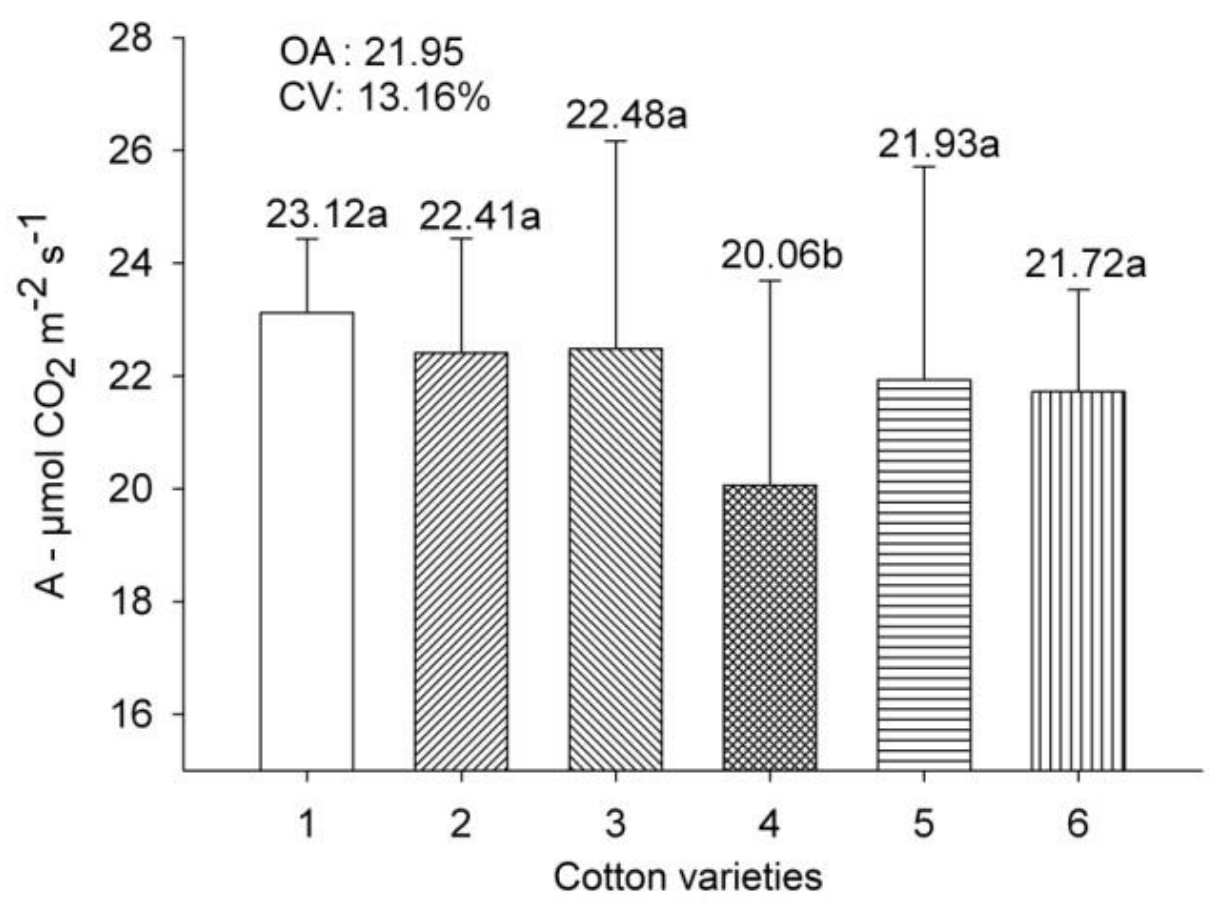

Figure 1. Average values of the $\mathrm{CO}_{2}$ assimilation rate (A) of the physiological characteristics of cotton cultivars. $\mathrm{OA}=$ Overall average; $\mathrm{CV}=$ Coefficient variation. 1 - IMA5801B2RF; 2 FM975WS; 3 - TMG47B2RF; 4 - TMG81WS; 5 - FM944GL and 6 - IACRDN. 


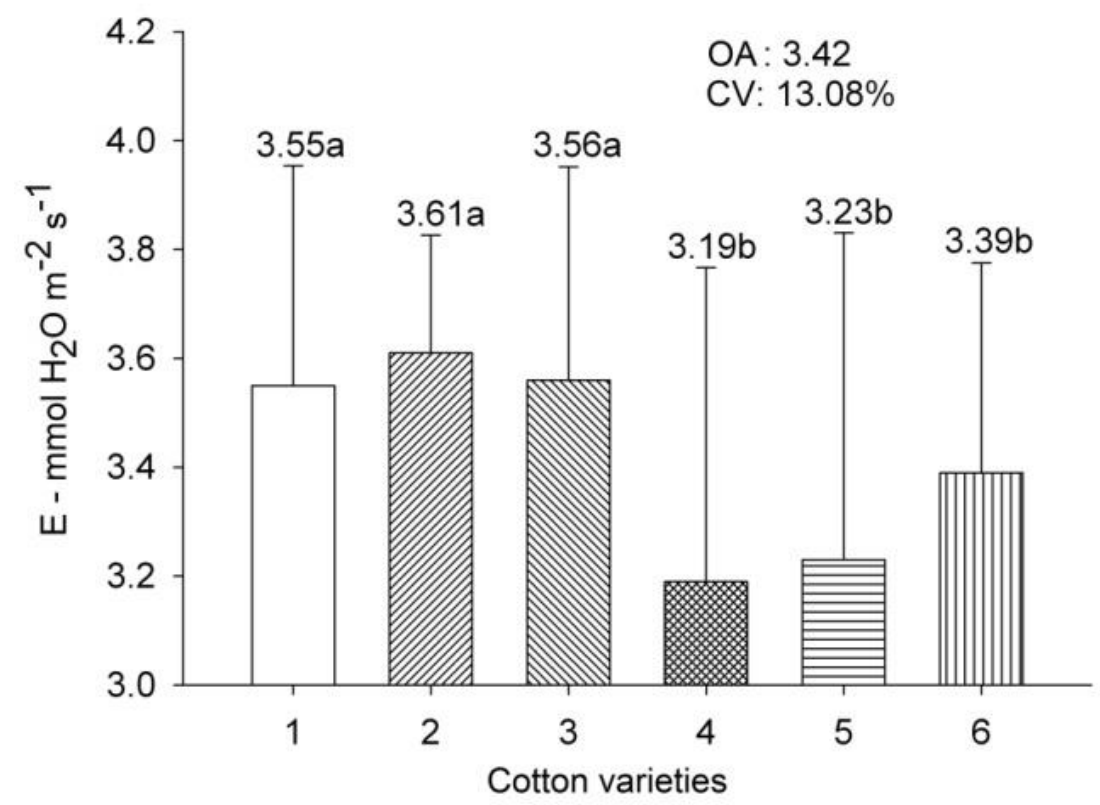

Figure 2. Average values of leaf transpiration $(\mathrm{E})$ of cotton cultivars. $\mathrm{OA}=$ Overall average; $\mathrm{CV}=$ Coefficient variation. 1 - IMA5801B2RF; 2 - FM975WS; 3 - TMG47B2RF; 4 - TMG81WS; 5 FM944GL and 6 - IACRDN.

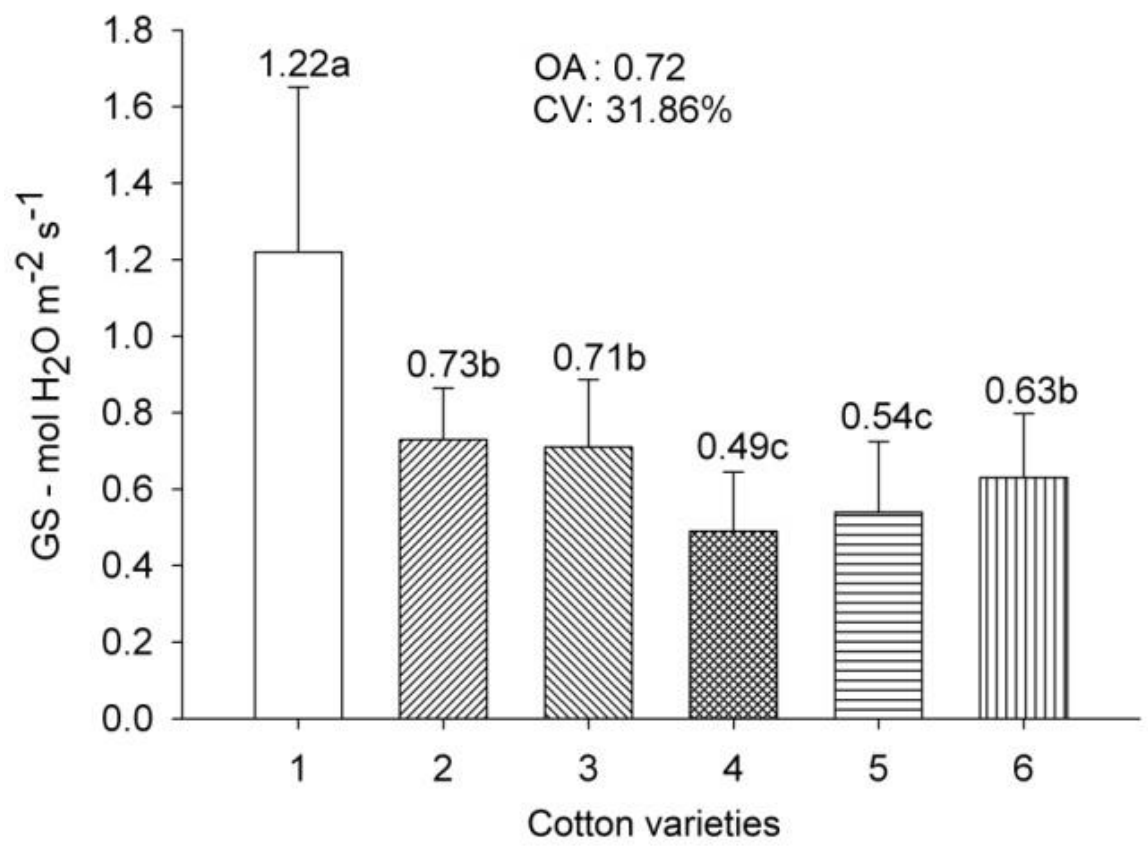

Figure 3. Average values of stomatal conductance (GS), of cotton cultivars. OA= Overall average; CV= Coefficient variation. 1 - IMA5801B2RF; 2 - FM975WS; 3 - TMG47B2RF; 4 - TMG81WS; 5 - FM944GL e 6 - IACRDN. 
The cotton cultivars IMA5801B2RF, FM975WS, TMG47B2RF and IACRDN had higher averages for the internal concentration of $\mathrm{CO}_{2}$ in the substomatic chamber. The lowest values were 248.96 and $251.64 \mu \mathrm{mol} \mathrm{mol}^{-1}$ for cultivars TMG81WS and FM944GL respectively (Figure 4). The internal $\mathrm{CO}_{2}$ concentration corresponding to the zero balance between the amounts of $\mathrm{CO}_{2}$ entering and leaving the substomatal chamber and defining the $\mathrm{CO}_{2}$ compensation point (Machado et al., 2005). Stomatal limitation would negatively affect photosynthetic performance, given that the greater the stomatal opening, the greater the diffusion of $\mathrm{CO}_{2}$ into the substomatic chamber (Silva et al., 2015).

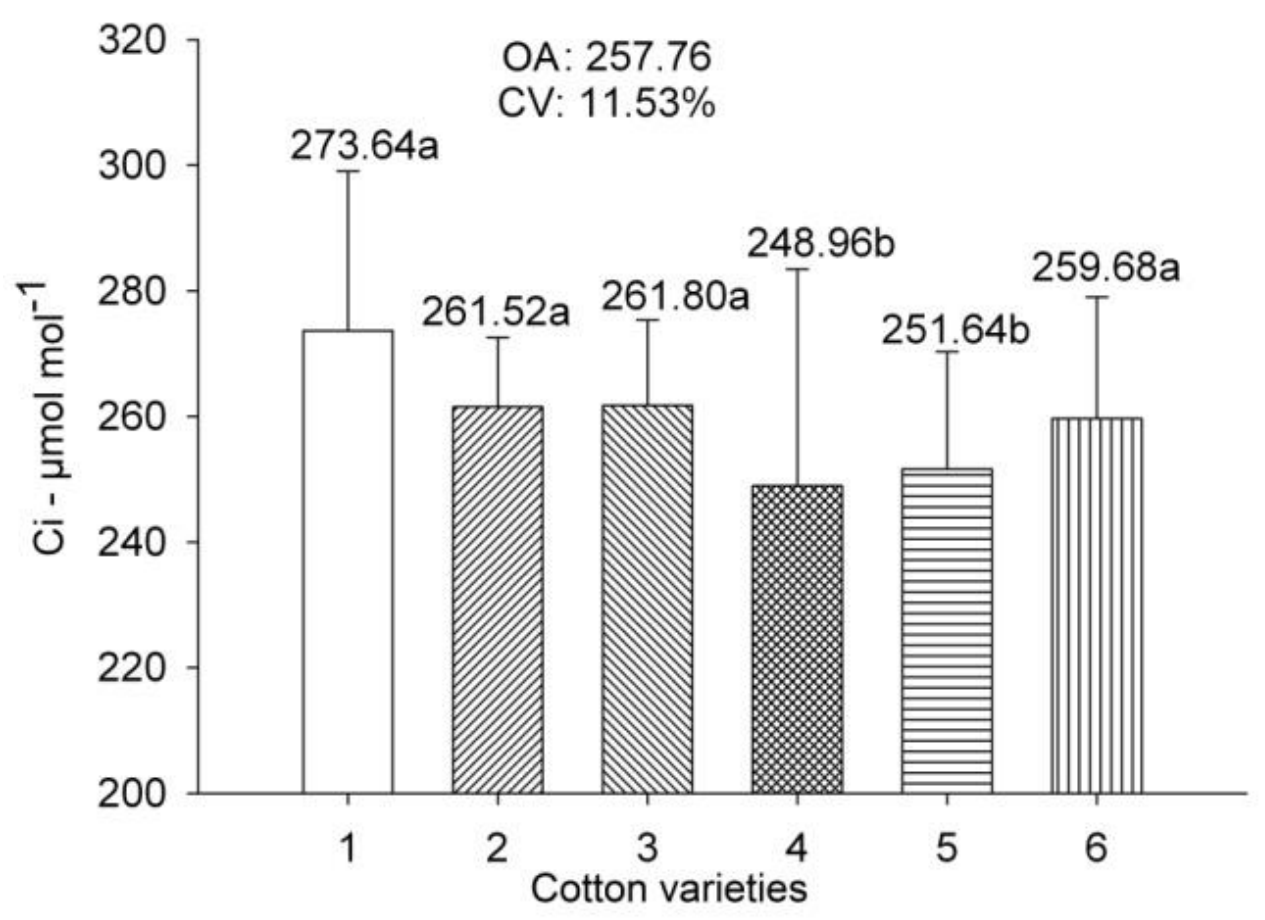

Figure 4. Average values of the internal $\mathrm{CO}_{2}$ concentration in the substomatic chamber $(\mathrm{Ci})$ of cotton cultivars. $\mathrm{OA}=$ Overall average; $\mathrm{CV}=$ Coefficient variation. 1 - IMA5801B2RF; 2 FM975WS; 3 - TMG47B2RF; 4 - TMG81WS; 5 - FM944GL e 6 - IACRDN.

The cultivars that showed the best efficient use of water were IMA5801B2RF, FM944GL and IACRDN with values between 6.45 to $6.66 \mathrm{~mol} \mathrm{CO}_{2}$ mol $\mathrm{H}_{2} \mathrm{O}^{-1}$ according to the Figure 5. The other cultivars had values of $6 \%$ lower approximately. The efficiency of water use in plants is correlated with the functioning of the stomatal apparatus, since this trait refers to the ratio between the amount of $\mathrm{CO}_{2}$ assimilated and the amount of water transpired by the plant (Lisboa et al., 2019). This trait of plants is an extremely important variable, as it is said the plant's capacity to resist drought conditions and irregular distribution, as well as excess water (Perazzo et al., 2013). 


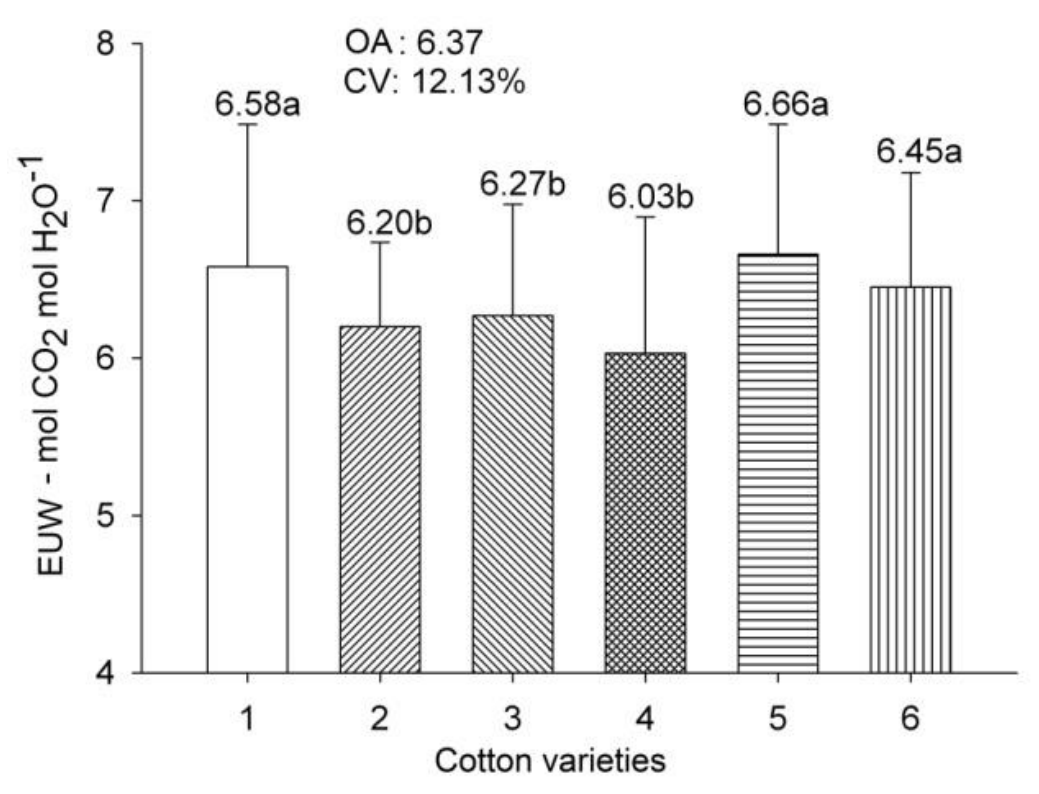

Figure 5. Average values of efficient use of water (EUW) of the physiological characteristics of cotton cultivars. $\mathrm{OA}=$ Overall average; $\mathrm{CV}=$ Coefficient variation. 1 - IMA5801B2RF; 2 FM975WS; 3 - TMG47B2RF; 4 - TMG81WS; 5 - FM944GL e 6 - IACRDN.

\section{CONCLUSION}

The cotton varieties showed different physiological characteristics, where the IMA5801B2RF variety had the lowest performance, which may reflect low productivity.

Further physiological studies are needed to understand the behavior of cotton varieties.

\section{REFERENCES}

ABRAPA, Associação Brasileira dos Produtores de Algodão. Disponível em https://www.abrapa.com.br>. Acesso em: 03 de março 2019.

APPA, Associação Paulista dos Produtores de Algodão. Disponível

em https://www.appasp.com.br>. Acesso em: 03 de março 2019.

Banzatto, D.A.; Kronka, S.N. (2013).
Beltrão, N.E.M.; Carvalho, L.P. (2004). Algodão colorido no Brasil, e em particular no Nordeste e no Estado da Paraíba. Brasília, Brasil: Embrapa Algodão-Documentos 128 (INFOTECA-E), 17p.

CONAB, Companhia Nacional de Abastecimento. (2019). Acompanhamento safra brasileira - Grãos. v.6 Safra 2018/19 Sexto levantamento, Brasília, p. 1-145.

EMPRESA BRASILEIRA DE PESQUISA AGROPECUÁRIA - EMBRAPA. Sistema brasileiro de classificação de solos. 3.ed. Brasília, 2013. 353p.

Fuzatto, M.G.; Cia, E.; Carvalho, L.H.; Kondo, J.I. (2014). Algodão. In: AGUIAR, A.T. Da E.; GONÇALVES, C.; PATERNIANI, M.E.A.G.Z.; TUCCI, M.L.S.; ASTRO, C.E.F. de (eds). Instruções agrícolas para as principais culturas

Experimentação Agrícola. 4.ed. Funep, 237p. 
econômicas. Campinas: Instituto Agronômico, p. 11-14. (Boletim Técnico, 200).

Galon, L.; Concenço, G.; Ferreira, E.A.; Aspiazú, I.; Silva, A.F.; Ferreira, F.A.; Silva, A.A.; Tironi, S.P.; Freitas, M.A.M.; Soares, E.R. (2010). Eficiência de uso da água em genótipos de cana-de-açúcar submetidos à aplicação de herbicidas. Planta daninha, 28(4): 777-784. https://doi.org/10.1590/S010083582010000400010

Lisboa, L.A.M.; Stelutti, A.; Lima, K.C.S.; Rafachinho, G.B.; Chedid, R.A.; Brenha, J.A.M.; Almeida, P.H.C.; Crispim, N.P.O.; Gabriel Banos Rodrigues, G.B.; Figueiredo, P.A.M. (2019). Physiological arameters of soybean under different intensities of artificial light. Journal of Agricultural Science, 11(8): 188195. https://doi.org/10.5539/jas.v11n8p188

Machado, E.C; Schmidt, P.T; Medina, C.L.; Ribeiro, R.V. (2005). Respostas da fotossíntese de três espécies de citros a fatores ambientais. Pesquisa agropecuária brasileira, 40(12): 1161-1170. http://dx.doi.org/10.1590/S0100204X2005001200002

Marur, C.J.; Faria, R.T. (2006). Photosynthesis of individual leaves in a coffee plant. Acta Scientiarium Agronomy, 28(3): 331-335. . http://dx.doi.org/10.4025/actasciagron.v28i3.94 1

Perazzo, A.F; Santos, E.M; Pinho, R.M.A; Campos, F.S; Ramos, J.P.D.F; Aquino, M.M.D; Bezerra, H.F.C. (2013). Características agronômicas e eficiência do uso da chuva em cultivares de sorgo no semiárido. Ciência Rural, 43(10): 1771-1776. https://doi.org/10.1590/S010384782013001000007
Pimentel, C. Metabolismo de carbono na agricultura tropical. Edur, 1998. 150p.

R DEVELOPMENT CORE TEAM (2009). R: A language and environment for statistical computing. $\mathrm{R}$ Foundation for Statistical Computing, Vienna, Austria. ISBN 3-90005107-0, URL http://www.R-project.org.

Raij, B.; Cantarella,H.; Quaggio, J.A.; Furlani, A.M.C. (1996) Recomendações de adubação e calagem para o Estado de São Paulo. 2.ed. Campinas: IAC, 285p.

Silva, F.G.; Dutra, W.F.; Dutra, A.F.; Oliveira, I.M.; Filgueiras, L.M.B.; Melo, A.S. (2015). Trocas gasosas e fluorescência da clorofila em plantas de berinjela sob lâminas de irrigação. Revista Brasileira de Engenharia Agrícola e Ambiental, 19(10): 946-952. http://dx.doi.org/10.1590/1807-

1929/agriambi.v19n10p946-952

Taiz, L.; Zeiger, E.; Moller, I. M.; Murphy, A. Fisiologia e desenvolvimento vegetal. 6. ed. Porto Alegre: Artmed, 2017. 858 p.

Tatagiba, S.D; Pezzopane, J.E. M; Reis, E.F. (2015). Fotossíntese em Eucalyptus sob diferentes condições edafoclimáticas. Revista Engenharia na Agricultura-Reveng, 23(4): 336-345.

https://doi.org/10.13083/reveng.v23i4.573

Teodoro, P.E.; Farrias, F.J.C.; Carvalho, L.P.; Ribeiro, L.P.; Nascimento, M.; Azevedo, C.F.; Cruz, C.D.; Bhering, L.L. (2019). Adaptability and stability of cotton genotypes regarding fiber yield and quality traits. Crop Science, 59: 1-7. https://doi.org/10.2135/cropsci2018.04.0250.

Xiong, D.; Douthe, C.; Flexas, J. (2018). Differential coordination of stomatal conductance, mesophyll conductance, and leaf 
hydraulic conductance in response to changing light across species. Plant, Cell \&

Environment, 41(2): 436-450.

https://doi.org/10.1111/pce.13111 